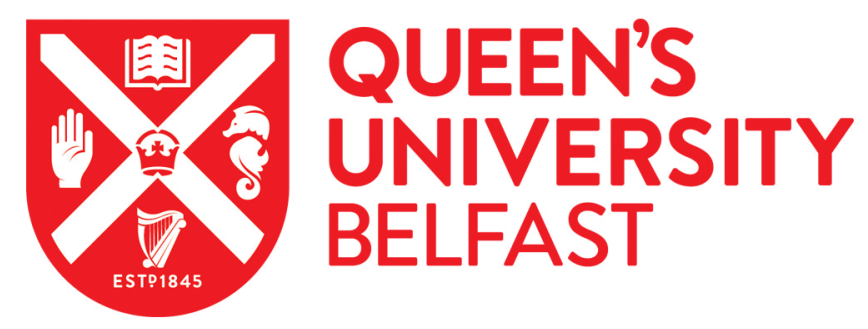

\title{
"I am in a constant state of insecurity trying to make ends meet, like our service users": Shared austerity reality between social workers and service users: Towards a preliminary conceptualization
}

Pentaraki, M. (2016). "I am in a constant state of insecurity trying to make ends meet, like our service users": Shared austerity reality between social workers and service users: Towards a preliminary conceptualization. British Journal of Social Work. https://doi.org/10.1093/bjsw/bcw099

Published in:

British Journal of Social Work

Document Version:

Peer reviewed version

Queen's University Belfast - Research Portal:

Link to publication record in Queen's University Belfast Research Portal

\footnotetext{
Publisher rights

๑ 2016 The Author. This is a pre-copyedited, author-produced PDF of an article accepted for publication in British journal Of Social Work following peer review. The version of record [insert complete citation information here] is available online at: http://bjsw.oxfordjournals.org/content/early/2016/08/31/bjsw.bcw099.
}

\section{General rights}

Copyright for the publications made accessible via the Queen's University Belfast Research Portal is retained by the author(s) and / or other copyright owners and it is a condition of accessing these publications that users recognise and abide by the legal requirements associated with these rights.

Take down policy

The Research Portal is Queen's institutional repository that provides access to Queen's research output. Every effort has been made to ensure that content in the Research Portal does not infringe any person's rights, or applicable UK laws. If you discover content in the Research Portal that you believe breaches copyright or violates any law, please contact openaccess@qub.ac.uk. 
This is a pre-print edition. The final edition can be found at the British Journal of Social Work (2016) 0, 1-17, doi: 10.1093/bjsw/bcw099

Advance Access published August 31, 2016

"I am in a constant state of insecurity trying to make ends meet, like our service users": Shared austerity reality between social workers and service users: Towards a preliminary conceptualization

\section{By Maria Pentaraki, Queen's University Belfast}

This article introduces the concept of an emerging shared austerity reality, which refers to the socio-economic context of austerity that is shared both by social workers and service users, albeit to different degrees. Traditionally, the concept of the shared reality has been utilized to encompass the experiences of welfare professionals working in situations where both they and service users are exposed to the adverse effects of a natural disaster, war or terrorist attack. Here, the concept of shared reality is expanded through the introduction of the context of austerity. Drawing on 21 in-depth interviews with public sector social work practitioners in Greece it discusses, among other things, social anxieties about their children's future, and their inability to take care of their elderly relatives that suggest an emerging shared austerity reality, reflecting the deterioration of socio-economic conditions. The paper ends with a discussion 
about the possibilities of alliance and division that emerge from the concept and future research directions. Moreover, it concludes with a reflection on the role of the social work profession and recent political developments in Greece in anti-austerity struggles.

Keywords: Neoliberalism, Greece, Shared Reality, Social Workers in Austerity, Grounded Hope

In recent years, a small but growing body of scholarly work has been addressing the concept of "shared reality" (Kretsch, et al., 1997), "shared traumatic reality” (Dekel and Baum, 2010; Nuttman-Shwartz et al., 2009) and "shared trauma” (Tosone et al., 2012). The features common to these three interrelated concepts are situations of shared reality in which welfare professionals and service users were exposed to the same collective disaster. The concept of shared reality has been applied to "situations in which the social worker not only helps the survivor of a traumatic event, but is also personally threatened and, in some cases, even hurt, by the same event; in these situations, both the social worker and the client are exposed to a similar threat” (Dekel and Baum, 2010: 1928; Baum, 2012). This phenomenon of shared reality includes large-scale events such as natural disasters, wars and terrorist attacks that expose both the service user and the welfare professional to the same reality. 
The present article, drawing on the critical tradition of social work which addresses the socio-economic context (author's own; Ferguson, 2009), seeks to expand the range of uses of the shared reality concept by introducing the concept of the shared austerity reality, which refers to the socio-economic context of austerity that is shared both by social workers and service users. Social workers not only help those aversely affected by austerity but also they are personally threatened by austerity measures too. Thus, it expands the concept of shared reality by introducing a new dimension, the one of the austerity context. The austerity context in this paper encompasses socioeconomic policies such as social spending cuts that have been rolled out in many countries world wide bringing "the pain of economic stagnation but hardly any of the promised benefits of debt reduction, renewed growth and prosperity. Nonetheless, support of such measures has remained strong among economists, politicians and substantial parts of the public” (Schui, 2014:1).

The concept of shared austerity reality is appropriate to use because it illuminates the ways in which socio-economic context influences the lived experiences of the service users as well as the professionals. This is consistent with a wide range of scholarly literature that has conceptualized social work as a contingent activity that operates and is influenced by the socio-economic context (Wallace and Pease, 2011; Baines et al., 2009; Aronson and Sammon, 2000). However, while this literature addresses how neoliberal transformations 
have impacted on social work practice they failed to address the impact on the personal lives of social workers. Thus, the present study starts to fill this gap. Before I present the research findings, I will discuss briefly the socio-economic and policy context of the shared reality that extends beyond Greek boundaries, i.e. neoliberal capitalism. The paper ends with a discussion about the possibilities of alliance and division that emerge from the concept and future research directions. Moreover, it concludes with a brief reflection on the role of the social work profession and recent political developments in Greece in antiausterity struggles.

The socio-economic context of shared austerity reality is one of austerity measures such as social spending cuts. These austerity measures are a key feature of neoliberal/structural social transformations that have been underway since the 1980s (Harvey, 2005), culminating in the global recession that started in 2008. In the first part of this recession the majority of the high-income countries engaged in increased social spending in order to offset the results of the crisis (OECD, 2014). Since 2009, the second phase of the crisis, a significant decline has been noted in the majority of these countries, except the U.S.A., with the most rapid decline recorded in Greece (OECD, 2014).

These social spending cuts/austerity measures were part of a Structural Adjustment Program (SAP) that was an imposed condition on loans Greece took from the International Monetary Fund (IMF), European Union (EU) and 
European Central Bank (ECB). Usually, a SAP comes attached to a loan that a country gets from international creditors such as the IMF and requires the country to be restructured (adjusted) along neoliberal lines (Harvey, 2005). Core features of a SAP are social spending cuts, privatization of public resources and deregulation of labour relations etc. (Harvey, 2005) and all of these have been part of the SAP imposed in Greece (Karamesini, 2015). For every ten public sector employees, such as social workers who retire or leave only one can be replaced. State budget allocations to municipalities, which are almost the exclusive providers of social care in Greece, have been reduced by 60\% (Karamesini, 2015). Amongst other changes are the reduction of pension benefits, the introduction of caps to the duration of unemployment benefits, the abolition of means tested rent subsidy, the restriction of eligibility criteria, such as community care to elderly people that has left approximately $30 \%$ to $40 \%$ of previous beneficiaries uncovered since it now targets only those living with unemployed relatives etc. (For a detailed analysis see Karamesini, 2015).

These austerity measures have been presented as inevitable and deserved within the country experiencing them, such as Greece, ignoring their classbased nature (authors own). Despite the predominant discourse blaming the people of Greece for the High Public Debt Crisis (HPDC), it was a consequence of class-based policies that successive Greek governments had implemented in Greece (authors, own) i.e. one of the lowest corporate taxation rates in the EU, 
one of the highest military spending levels worldwide , and the implementation of a high bank bailout (for a detailed discussion about the factors that led to the HPDC see author's own, 2013).This was facilitated by the global elite's skilful transformation of a capitalist crisis into a crisis of public finances, and consequently into a HPDC (Levitas, 2012) in order to preserve “capitalism and the wealth and power of its elites" (McNally, 2011, 5) and the power of the establishment (Jones, 2014). It entailed the "massive transfer of wealth from the poor to the rich that funded the rescue of the world banking system, the bailout of corporations, and the salvage of the investment portfolios of the wealthy” (McNally, 2011, 5). As such, state resources that were previously allocated to welfare provisions were withdrawn or decreased under the pretext of an HPDC, and transferred to the finance capital. It is estimated that in 2015, public monies spent servicing the country's debt will be more than the money spent on social protection and healthcare— — $€ 23,400$ million and $€ 15,620$ million, respectively (Hellenic Parliament, 2011). It is worth noting that the new loan the Greek government was forced to agree to in July 2015 will be directed mostly to servicing previous loans according to the SAP requirements. This will lead to further deterioration of socio-economic conditions (ANAMPA, 2015).

Apart from the social spending cuts, a number of countries in the EU along with Greece have engaged in structural reforms following neoliberal lines (Hermann, 2014). Neoliberal policies are based on market fundamentalism and 
the withdrawal of state interventions from welfare functions (Harvey, 2005). Accordingly, the main characteristics of these structural reforms are deregulation and undermining of the labour conditions and social protection mechanisms (Hermann, 2014) that have resulted in a deterioration of the socioeconomic conditions and a growing level of inequality.

This growing inequality has resulted in the deterioration of the socioeconomic conditions of the majority of the people and the intensification of social problems (Wilkinson and Pickett, 2009) not only in Greece but in many other countries too. It has also led to the worsening of socio-economic conditions for the middle class as well as for the poor (Dorling, 2014; Winkelmann and Winkelmann, 2010). Public sector jobs, such as those connected to the welfare state are undermined and disproportionately affect women (Karamessini and Rubery, 2014). Public sector social workers have traditionally been part of the middle class enjoying secure employment conditions that now no longer exist due to the austerity and structural reform measures

Through the implementation of the social spending cuts, socio-economic conditions in Greece rapidly deteriorated with the country failing by 7 places in the UN’s Human Development Index Ranking of the UN (UN 2011 \& 2014). 
Having outlined the socio-economic context from which this shared reality emerges the article now turns to presenting the study.

\section{Research Methodology}

The research reported here is a component of a larger explorative study that sought to examine the perceived impact of the austerity and SAP measures on social workers in Greece as well as their response to it. One of the themes identified was that of shared reality and the article reports on this theme.

The research draws on 21 qualitative in-depth interviews with public sector $^{\mathrm{i}}$ generalist social workers working in county welfare departments and municipalities, as well as the social services of hospitals. Both are examples of state-mediated settings highly affected by the imposed policies. These two sectors are considered established social work employment sectors for social workers in Greece and are those that are mostly approached by service users with no or little access to resources.

Lack of documentation on the total picture of state social services led to the selection of participants by purposeful and snowball sampling. At the start of the research the author had informal discussions with key informants, i.e. members of the Committee of the Greek Association of Social Workers, practitioners and Greek social work academics. The proposed selection criteria were presented to the key informants. The selection criteria of participants were that they: a) were currently working as public sector social workers, either in the 
social services of a hospital or a welfare office; 2) represented a variety of geographical areas, overall; and 3) had at least two years of experience. The names of some social workers meeting these criteria were proposed. After the initial interviews, which followed a purposeful sampling technique, the rest of the participants participated through a combination of snowballing and purposeful sample techniques. Participants gave signed consent to the interview. They were informed about the research and that the content of the interviews might be included in a publication. They were assured that identifiable information was not going to be included. Accordingly, their geographical and organizational locations were described in very general terms. The design and conduct was approved by X university.

Twenty one ${ }^{\mathrm{ii}}$ public sector social workers, all women, indicative of the disproportional representation of women in the social work force in Greece (Dedoussi, et al., 2004) and worldwide, were interviewed, from five different cities/towns, including the greater area of the capital city, Athens, which accounts for almost half of the population of Greece. Since the number of public sector social workers in each city is very small, the remaining cities are not mentioned, in order to protect the anonymity of the participants. The participating social workers from outside Metropolitan Athens were based in other urban locations that also included semi-rural, rural, and other remote settings; i.e. islands in their area of professional practice. At the time of the interviews all participants held permanent public sector jobs but policy 
proposals that the permanency will be undermined were debated. Their ages ranged from the early thirties to early fifties and were all white women born in Greece. At their highest level of education, two participants held two postgraduate degrees in Social Work; six participants held two degrees, one of which was a social work degree; and the rest held undergraduate degrees in social work. In line with social work practitioners’ practice in Greece all of them had an undergraduate social work degree. The work experience of the social workers ranged from 3 to 25 years.

The data were gathered through a qualitative research methodology involving semi-structured in-depth interviews. The main question, elaborated on in this research, was: "How have you been impacted by the SAP/ austerity measures?”. The respondents were given the opportunity to elaborate at their discretion. The interviews were conducted in Greek by the author, between September 2010 and September 2011 ${ }^{1}$. The majority of the interviews lasted from 40 to 50 minutes. The interviews were analysed thematically, in order to identify, analyze, and report patterns (themes) within the data (Braun and Clarke, 2006). After careful review of the transcripts the author used participants' narratives to identify key words and phrases that were then coded, interpreted and themed. These main themes, supplemented by selected quotations by particpants, provide the basis for the analysis and discussion of findings. 


\section{Research Findings}

Primarily, the findings indicate that social workers are adversely affected by the context of austerity and the neoliberal structural reforms suggesting an emerging shared reality between service users and public sector social workers in Greece. It needs to be noted though that public sector social workers are not affected to the same extent as the service users, but nevertheless, the context of austerity gives rise to feelings of vulnerability for almost everyone living in Greece. Participants were directly asked how the austerity measures/SAP measures have influenced them personally and they all acknowledged the unfairness of the salary cuts. Moreover, all of the respondents, except two, discussed either directly or indirectly, how the cuts have influenced their lives. The two respondents who refused to go into details on how their lives have been influenced, quickly brushed the question aside. One of the participants characteristically mentioned, “[...] of course the cuts influence us [....] but $[\ldots .$.$] this is the amount of money we make and with that amount of money we$ need to make ends meet”. The same member continued to discuss the people who do not have jobs.

This differentiation might be attributed to a number of factors which, according to each participant's values influences their response. Among these factors might be those embodied in professional discourses of boundary settings that might prevent some social workers discussing the impact of the cuts in their lives after they had been discussing the impact of the cuts on their social users 
lives, i.e. it might be a way to distance themselves from the service users. Another set of influencing factors might be those embodied in the dominant elite’s rhetoric of doing ones duty and tolerating sacrifices (Markantonatou, 2012) and /or for being a deserved victim since "we are all to blame” (author's own) that some social workers might have espoused. Another factor might be a high combined household income of the respondent which was not explored here and is worthwhile exploring in future research.

The rest of the findings centred on two themes. The first theme is an acknowledged similarity between themselves and the service users and the second theme relates to the social anxieties due to their inability to fulfil their family responsibilities towards their children and elderly relatives. These two themes are explored respectively below.

\section{1. "I am in a constant state of insecurity trying to make ends meet, like our service users" Direct and indirect acknowledgment of similarities of the social workers between themselves and the service users}

The decrease in their wages and the changes in the policy context have given some of the respondents new insights about the connections between themselves and the service users. It was out of this theme that the main argument of the paper emerged. 
A respondent from a welfare department located in an urban centre compared her state of insecurity with the state of insecurity that service users face:

"My husband and I had a combined salary that enabled us to lead a decent life. Now my husband has died and my low salary is not enough to meet the needs of myself and my two children. Since his death, I am in a constant state of insecurity trying to make ends meet, like our service users. I have been trying to get his pension, but there are so many bureaucratic hurdles. The changes that the economic crisis brought in the social security area make it much worse, as no one seems to be able to tell me when and if I will get his pension, and how much will that be. I am a working professional and I face so many problems. Can you imagine what happens to the service users [who are dealing with all these policy changes]?" Another respondent stated, "The money I am making is not enough. I am making 830 euros a month, after I pay rent and the utilities bills there is no money left. A lot of our colleagues face a similar situation. Can you believe that I already have three offers from colleagues to become roommates? [sharing houses has not been a common practice in Greece before the crisis] No one from our office had 
money to go for vacations. I feel very close to being a service user.” (Social worker in a welfare department office locating in a semi-urban area)

Furthermore, a hospital social worker in an urban setting identified similarities between the service users and herself when discussing her inability to offer any substantial help to the service users due to austerity measures. She stated:

"I just remain here fooling myself that I do something, but the only thing I do is ...to talk to people when they come to me ...Thus, I empower him/her so they can breathe for a couple of more days until they come back to us. The only thing I do is to empathise ...because you are also in the same difficult position as him/her in terms that we have become poorer...”

Participants also reported an increase in social isolation due to their recently constrained financial ability to either invite friends over their house or to participate in social events as they used to do. As a respondent stated: "I have stopped inviting friends home because of the cost. Everything costs. You can't even afford to buy sodas to treat your friends. So you stop inviting them”. This quote alludes not only to increased isolation, but also to stress due to their inability to meet the socially defined expectations of hospitality. These findings 
suggest deteriorating material conditions which undermine their

status. They struggle to make ends meet. They have to consider living in shared accommodation; they cannot go on vacation. All these changes led them to acknowledge similarities between them and the lives of the service users.

\section{2. "Families are under extreme hardships [to fulfil their familial} responsibilities]": The rise of social anxieties due to their inability to fulfil their family responsibilities towards their children and elderly relatives

The changing socio-economic conditions that resulted in decreased salaries and pensions among other things, gave rise to concerns about their children's future and the care of their elderly relatives. One respondent characteristically stated that:

My daughter is really talented in ballet dreaming to become a famous ballet dancer. Before our salaries decreased [referring to the household income] we were paying for anything she needed to make sure that her dream was going to come through. Private lessons, attendance of performance of famous ballets...Now we have to stop her from the private lessons and we do not know how to tell her. That will devastate her. Before the crisis we were discussing that right after high school she would go abroad to study in a famous ballet school now this is out of the 
question. We need to discuss this with her too and we do not know how. In a couple of weeks a famous ballet is coming to perform, before our salary decreases we were making that a family outing. The whole family was going with my daughter to enjoy the ballet. Now we only bought one ticket, the cheapest one. Her father will take her to the performance but he won't join her. He will wait outside in the foyer for her.

This statement reflects that they clearly cannot sustain the middle class aspirations of their children's future. It also suggests that some of the certainties they had in life, such as the ability to allocate household income for their child's education, is now lost.

One participant stated characteristically that she is afraid that her children will be worse off than herself even though she herself did better than her family. Another, stated that “Twice a week I attend a professional development course which is self-funded. I am thinking that just in case something happens to my job so that I will be able to go into private practice. I have a family to support. I also tutor my daughter, almost every evening. I have to make sure that she does well at school so she can make it as an adult”. Respondents who talked about their children were the ones whose children were of school age. Traditionally, there has been an expectation that university educated white-collar workers' status will improve progressively over the life course and across the generations. This has been a central aspirational goal of 
the middle class that was grounded in the material conditions of the social democratic phase of capitalism. The actualization of this aspiration has been undermined by the socio-economic conditions of neoliberal capitalism such as austerity measures. The predictability of a career path that used to exist does not exist any more.

This sense of insecurity about their children's future has also been identified elsewhere and has been shown to be associated with pessimistic attitudes about the future (Ipsos MORI Global Trends Survey 2014). Therefore, young people’s futures are being undermined because of high levels of unemployment, rising university fees and so forth.

Despite these attitudes, the respondents seem to emphasize their professional development and the educational achievement of their children. This became evident after respondents were asked how they deal with this insecurity. The majority of respondents were either furthering their professional qualifications by attending self funded professional development courses; looking into starting them in the future; inquiring about Ph.D. opportunities or opportunities to work outside Greece. Additionally, there were a small number of respondents who were participating in collective actions, such as strikes or the Greek equivalent of the Occupy movement that were underway around the time the interviews were held. The extent of their participation in collective actions was varied and constrained by family responsibilities. It is worthwhile to explore in future 
research if the participation varied along gender lines. One respondent stated that she did not participate in any struggles outside working time as she had her professional development course to pursue along with family responsibilities to her child. She continued to explain that she is putting much more emphasis on her daughter's ability to do well at school as a way to enhance her future employment prospects. Despite their participation, or not, in collective actions to resist austerity and the structural reforms, all were actively trying to pursue an individualistic career advancement strategy. This represents an ambivalent stance towards the insecurity of living in austerity times. On the one hand they criticized austerity but on the other they undertook actions to try to maintain the traditional expected trajectories of upward mobility in a socio-economic environment that no longer supports it.

Apart from the respondents' concerns about their children's future an anxiety about their ability to care for their elders was also expressed. In the context of discussing their inability to proceed with discharge plans for elderly patients, medical social workers emphasized that families can no longer provide the care that is needed for the recovery of a family member due to increased economic hardship. Some of the respondents highlighted similar difficulties that they themselves were facing in taking care of their elderly parents.

Families are under extreme hardships [to maintain and fulfil their familial responsibilities]...Families that used to take care their elderly 
through paying a carer by 600 euros a month (such as an immigrant woman from Albania) so they can take care the sick now they cannot any more...The same relates to us, we could help our parents by paying a live in carer so they could keep living at their home now we cannot do that any more...

The socio-economic conditions that existed in the pre-crisis Greece as well as other countries allowed middle-income families to meet the needs of elderly care by employing female migrants (Bettio et al., 2006). Now in the context of austerity, both public provision of elderly care as well as family care are undermined and this will increase the pressures placed mostly on women due to prevailing gender roles to provide needed elderly care, thereby raising concerns about an undermining of gender equality (Karamesini and Rubery 2014). In Greece, this will become even more evident during the next decades, as it becomes an increasingly 'greying' country in which it is projected to have an higher than the average EU percentage of people over 65 years old (Eurostat, 2011).

\section{Discussion}

As Harvey (2005:3) has argued, neoliberalism entails both a specific economic process and a reconfiguration of society which brings with it much “creative destruction” of prior institutional frameworks, divisions of labour, social relations, welfare divisions, reproductive activities and ways of life. 
Among these changes that Harvey (2005) discusses are those that the research respondents talked about. These reflect the shattering of the absolutisms of everyday life. The findings suggest that the social anxieties of public sector social workers are related to their inability to sustain their pre-crisis material conditions (their middle class status), to ensure the social mobility of their children, and to support their elderly parents are evident in the findings. They also concur with Bauman's discussion of the concept of individuation (2000) which he asserts emerges out of society that is characterized by modern liquidity as neoliberal policies progressively undermine the social protection net and people are left to find their own solutions. Individuation is suggested in these findings by participants' attempts to advance their own career and to ensure their children's career prospects by intensifying their home based parental education support. Thus, they try to find individual solutions to wider structural problems. This is in accordance with Beck's assertion that "how one lives becomes a biographical solution to systemic contradictions” (Beck,1992:137). Furthermore, the findings suggest the dissolution of the beliefs that allow people to experience the world as stable, predicable and safe, no longer exist and their loss can be traumatic (Stolorow, 2007; 2009). Within the context of economic crisis, people feel vulnerable and undermined by these constant challenges and threatened by the potential impacts of economic collapse. This has led Stolorow (2007; 2009) to conceptualize economic crisis as collective trauma. Insecurity is no longer only a characteristic of service 
users living in poverty, it is something that educated white-collar professionals such as social workers are now experiencing. Of course there is a variation in the experiences of social workers and service users, but the underlying background of their lives is similar and therefore suggests the possibility of the use of the concept of shared austerity reality.

Public sector social workers ${ }^{2}$ struggle to make ends meet. Certain aspects of their lives are shaped through socio-economic processes brought about by the neoliberal SAP policies. This is reflected in how their personal troubles, i.e. their social anxieties and the deterioration of their material conditions, are connected to public issues (Mills, 1959), namely the socio-economic context of austerity and neoliberal structural reforms. Hence, both service users and social workers are adversely affected by austerity measures.

This shared austerity reality has been discussed elsewhere as an acknowledged shared commonality by a member of the executive committee of the Greek Professional Association of Social Workers, (AuthorsOwn). It has also been referred to as a "double jeopardy” for service users and care workers who "are adversely affected by neoliberal public policy" (Abramovitz and Zelnick, 2010: 97).

Will that acknowledged shared reality result in an acknowledgement of shared class interest? and moreover, to shared collective action as the motto 'We are the 99\%" of the Occupy social movement indicates? Will it lead to alliances or will it lead to divisions? A number of social work scholars from the 
critical tradition (among others see: Ferguson \& Woodward, 2009; Ferguson, 2008) make normative claims about the necessity of building alliances among social work practitioners and service users, due to an acknowledged shared interest. This acknowledged shared interest has occurred mostly on the part of social workers who have stated that they had participated in collective struggles of resistance both before and after the onset of the austerity measures. In future research, it will be interesting to explore whether shared austerity reality between social workers and service users will result in unified and collective action or lead to further division. The fact that the social workers who took up collective action prior to the economic recession and austerity measures being implemented are the ones now more likely to act in the fight against austerity, suggests that these social workers are the ones who have long considered that structural inequalities exist and fought for the improvement of service users' conditions possibly due to their values and, crucially, broader structural understanding. Their motivation to take part in collective action is therefore not necessarily inspired by selfish reasons but as a continuation of their fight against inequality in society. It is then a separate consideration whether they will now be another set of social workers who take collective action due to a "shared interest" i.e., because of shared austerity reality. Whether or not they comprise yet another set of social workers who take collective action due to a "shared interest" in this case because of shared austerity reality. It remains to be seen whether the worsening socio-economic conditions will transform this 
acknowledged shared reality into a joint platform of action or will it lead to divisions which could include a revival of scapegoating attitudes towards immigrants, and welfare recipients. The broader political context in Greece illustrates that both the possibilities of alliances and divisions exist. The election of the Radical Coalition of the Left (SYRIZA) demonstrates the reality of alliances but on the other hand the 18 MPs of Golden Dawn, a far right neoNazi party with a strong anti-immigrant rhetoric show that divisions are brewing. The social work profession is not immune from this racist rhetoric as exemplified by two medical social workers who blamed the collapse of public sector hospitals on uninsured immigrants (author's own). Furthermore, the current reluctance of the EU through the Eurogroup (Finance ministers of the EU countries), to accept the anti-austerity measures proposed by the coalition government of SYRIZA (author's own) may contribute to furthering the rise of the extreme right in Greece and elsewhere and exacerbate the divisions. So whether shared austerity reality will lead to alliances or divisions is still to be resolved and will depend on the direction of the overall socio-economic context. Future research is needed to address the question of alliances and divisions as this will contribute to furthering understanding of the impacts of the financial crisis and its ensuing austerity measures.

This paper has introduced the concept of shared austerity reality, a concept that refers to the adverse consequences of austerity on both service users and social workers. This concept is relevant to social workers outside Greece too. It 
will be useful to be explored through cases of indebtedness, for example, social work students with student loans working with service users during their placement, or social work graduates also indebted through student loans who are struggling to pay off their loans at the same time as working under insecure funding conditions of NGOs and Charities. It may also be relevant in the case of social work academics teaching under the threat of redundancy due to budget cuts. Future social work research is also needed to explore if the pressures experienced by the austerity context enhances or undermines social workers' professional, family and community functioning. The following questions are just some of those that can be addressed in further research. Are these experiences empowering or disempowering? Do these experiences lead to an increase or decrease of empathy towards the service users? Do these experiences enable social workers to have a more contextual and less victim blaming understanding of the service users' needs and concerns? Is there a difference in responses and experiences according to the value orientation, gender, class or other socio demographic factors of the social workers? What is the role of the social work profession in responding to the context of austerity? Is a stronger collective professional voice emerging against austerity because of these experiences? Is there a stronger collective action with service users emerging? All these are questions that can be addressed in future research. It is without doubt that the austerity context and neoliberal transformations pose numerous challenges to the social work profession. Social workers face 
pressures both professionally and personally which are created by the austerity context. On one hand they struggle to meet the rising demands at work (authors own) and the needs of the increased numbers of service users who have lost their jobs, have become impoverished and face increasing insecurities and anxieties. Social workers are left to struggle in an under resourced social service environment and as one participant sated the only thing they can do is to empathise. On the other hand, in their personal lives they themselves experience increasing insecurities and anxieties. How these experiences will be resolved remains to be seen.

Many scholars from the critical social work tradition (author's own, Ferguson, 2009; Ioakimidis, 2014 et al.) argue for the articulation of political agency of the social work profession by reference to the deteriorating socioeconomic conditions and the social justice mandate of the profession. This claim could be very easily accused of “naïve possibilitarianism” (Whitty 2001, p. 288). However, by critically employing Gramsci’s conceptualization of Hope as reflected in his famous quote "optimism of the will pessimism of the intellect”. I argue that the social justice value base aspiration of the social work profession can contribute to struggles for social justice that challenge the neoliberal socio-economic context. This necessitates that the social work profession goes beyond the rhetorical affirmation of its value base and acknowledges the difficulties of attaining social justice (Conneely and Garrett, 2015). Also, at the same time, the social work profession should recognise the 
possibilities of human agency to overcome those difficulties. Grace (2011) has called this “complex hope” (2011: 855-856) I have called this "grounded hope” (author's own) to denote the recognition of the structural difficulties and at the same time the belief in human agency to overcome them. As I have argued elsewhere, the value base of the profession can be emancipatory so long as it moves beyond its rhetorical affirmation and aims to actively engage in struggles and coalition building with other progressive forces (author's own).

Neoliberalism, which is the context of austerity, brings much distress, insecurity, unemployment, etc. (Harvey, 2005), to the majority of the population, instead of its promised benefits which have only been experienced by a few (Harvey, 2005), needs to be challenged as it is not the only possible economic system. The social work profession can play a role towards delegitimizing the ideological supremacy of neoliberalism (author's own) but this is not enough. The social work profession should form broad coalitions with service users, other progressive forces, such as trades unions across EU and articulate a vision of another society; a society structured along human needs (author's own). This is something that the Social Work Action Network, already does (author's own) The recent political developments in Greece in which austerity is furthered, despite the election of an initially anti-austerity coalition, highlights the need of European anti-austerity cross-national coalitions and for anti-austerity governments to be elected throughout the EU. This is in order to challenge austerity policies and the Neoliberal New European 
Economic Governance policy framework which institutionalizes permanent austerity (author's own; Degryse, 2012)and to shape the EU and consequently each member country by the needs of the people rather the needs of the finance capital. Whether or not this realization, along with the shared austerity reality that social workers experience, will help towards this direction remains to be seen.

\section{References}

Abramovitz, M. and Zelnick, J. (2010) 'Double jeopardy: the impact of neoliberalism on care workers in the United States and South Africa', International Journal of Health Services, 40 (1), pp. 175-186.

Aronson, J. and Sammon, S. (2000) 'Practice amid social service cuts: Working with the contradictions of "small victories", Social Work Review, 17(2), pp. 167-187.

ANAMPA (2015). Interview of Stinglitz given to ANAMPA available at http://www.amna.gr/webtv/83899/Tz.-Stigklits-sto-APE:-Sumfonia-me-topistoli-ston-krotafo (23/07/2015).

Baines, D., MacKenzie Davis, J. and Saini, M. (2009) ‘ Wages, working conditions, and restructuring in Ontario’s social work profession' Canadian Social Work Review/Revue Canadienne de Service Social, 26 (1), pp. 59-72. 
Bauman, Z. (2000) Liquid Modernity, Cambridge: Polity Press.

Baum, N. (2012) 'Emergency routine’: The experience of professionals in a shared traumatic reality of war', British Journal of Social Work , 42 (3), pp.424 $-442$.

Beck, U. (1992) Risk Society: Towards a New Modernity, London: Sage.

Braun, V. and Clarke, V. (2006) 'Using thematic analysis in psychology’ Qualitative Research in Psychology, 3(2), pp. 77-101.

Conneely, E. and Garrett, P.M. (2015) 'Social workers and social justice during a period of intensive neoliberalization: A preliminary investigation from the Republic of Ireland’ Journal of Progressive Human Services, 26(2), pp. 126147.

Dedoussi A-A, Gregory S, Georgoussi E, Kyriopoulos J (2004) ‘Social workers in Greece: who they are and where they work', International Social Work 47, pp. 259-274.

Degryse, C., (2012) The New European Economic Governance (November 30, 2012). ETUI Working Paper 2012.14. Available at SSRN:

http://ssrn.com/abstract=2202702 or http://dx.doi.org/10.2139/ssrn.2202702 $(23 / 07 / 2015)$ 
Dekel, R. and Baum, N. (2010) 'Intervention in a shared traumatic reality: A new challenge for social workers', British Journal of Social Work, 40, pp. 19271944.

Ferguson, I. (2008) Reclaiming Social Work: Challenging Neoliberalism And Promoting Social Justice, London: Sage.

Ferguson, I. and Woodward, R. (2009) Radical Social Work in Practice, Policy Press: Bristol.

Grace, G. R. (2011) ‘Book reviews: Education and poverty in affluent countries', Journal of Education Policy, 26(6), pp. 855-860.

Harvey, D. (2005) A Brief History of Neoliberalism, Oxford: Oxford University Press.

Hermann, C. (2014) 'Structural adjustment and neoliberal convergence in labour markets and welfare: The impact of the crisis and austerity measures on European Economic and Social Models', Competition and Change, 18(2), pp. $111-130$.

Hellenic Parliament. (2011). Medium-term fiscal strategy (2012-2015).

Hellenic Parliament. Retrieved from:

http://www.hellenicparliament.gr/Nomothetiko-Ergo/Katatethenta-

Nomosxedia?law_id=def41269-857a-42c8-8073-12ff75bfefbf 
Institute of Labour. (2011) The Greek Economy and Labour, Annual Report. Athens: Institute of Labour.

Ioakimidis, V., Cruz Santos, C. and Martinez Herrero, I. (2014)

'Reconceptualizing social work in times of crisis: An examination of the cases of Greece, Spain and Portugal', International Social Work, 57(4), pp. 285-300.

Jones, C. (2001) 'Voices from the front-line: State social workers and New Labour', British Journal of Social Work, 31, pp. 547-62.

Jones, O. (2015) The Establishment: And How They Get Away With It, Rickmansworth: Penguin.

Ipsos MORI Global Trends Survey. (2014) People in western countries pessimistic about future for young people. Retrieved from https://www.ipsosmori.com/researchpublications/researcharchive/3369/People-in-westerncountries-pessimistic-about-future-for-young-people.aspx

Karamessini, M. (2015). 5. The Greek social model: Towards a deregulated labour market and residual social protection in Daniel Vaughan-Whitehead (ed) The European Social Model in Crisis: Is Europe Losing Its Soul?, Cheltenham: EdwardElgar Publishing, 230-288. 
Karamessini M. and Rubery, J. (eds.). (2014) Women and Austerity: The Economic Crisis and the Future for Gender Equality, New York: Routledge.

Kretsch, R., Benyakar, M., Baruch, E., and Roth, M. (1997) A shared reality of psychotherapists and survivors in a national crisis as illustrated by the Gulf War. Psychotherapy: Theory, Research, Practice, Training, 34, pp. 28-33.

Lev-Wiesel, R., Goldblatt, H., Eisikovits, Z. and Admi, H. (2009) ‘Growth in the shadow of war: The case of social workers in a shared war reality', British Journal of Social Work, 39 (6), pp. 1154-1174.

Levitas, R. (2012) 'The just's umbrella: Austerity and the big society in coalition policy and beyond', Critical Social Policy, 32(3), pp. 320-342.

MacLeavy, J. (2010) 'Remaking the welfare state: From safety net to trampoline', in Birch, K. and Mykhnenko, V. (eds.), The Rise and Fall Of Neoliberalism: The Collapse Of An Economic Order? New York: Zed Books.

McDonald, C., Harris J. and Wintersteen, R. (2003) 'Contingent on context? Social work in Australia, Britain, and the USA', British Journal of Social Work, 33(2), 191-208.

Markantonatou, M. (2012) 'The social consequences of the financial crisis in Greece: Insecurity, recession and welfare deregulation’, International Journal of Anthropology, 27(3), pp. 183-196. 
Mishra, R. (1999) Globalization and the Welfare State, Cheltenham: Edward Elgar.

Mills, C.W. (1959) The Sociological Imagination, New York: Oxford University Press.

Nuttman-Shwartz, O. and Dekel, R. (2009) 'Challenges for students working in a shared traumatic reality', British Journal of Social Work , 39 (3) pp. 522-538. OECD. (2014) Society at a Glance. The Crisis and its Aftermath, Paris: OECD. Parton, N.(1996) Social Theory, Social Change and Social Work, London: Routledge.

Stolorow, R. (2007) Trauma and Human Existence, New York: Routledge.

Stolorow, R. (2009) 'The economic crisis as collective trauma', Trauma Psychology Newsletter, 4 (2), pp. 5.

Tosone, C., Nuttman-Shwartz, O. and Stephens, T. (2012) 'Shared trauma: When the professional is personal', Clinical Social Work Journal, 40, pp. 231239.

Wallace, J., and Pease, B. (2011) ‘ Neoliberalism and Australian social work: Accommodation or resistance', Journal of Social Work, 11(2), pp. 132-142. 
Wilkinson, R., and Pickett, K. (2009) The Spirit Level (Why More Equal Societies Almost Always Do Better), London: Allen Lane.

Whitty, G. (2001) ‘Education, social class and social exclusion’, Journal of Education Policy, 16(4), pp. 287-295.

Winkelmann, L. and Winkelmann, R. (2010) 'Does inequality harm the middle class?’ KYKLOS, 63 (2), pp. 301-316.

Zacharias, K. (2012). 10.000 beds will disappear from public hospitals. Available at http://stokokkino.gr/fakeloi/krisi/tha-eksafanistoys-10.000-klinesapo-ta-dimosia-nosokomeia/view (09/08/2012) 